\title{
Seasonal variation in Importance Value Index (IVI), Diversity Indices and Biomass of aquatic macrophytes at Biratnagar and adjoining areas, eastern Nepal
}

\author{
Bhabindra Niroula ${ }^{1^{*}}$ and K.L.B. Singh ${ }^{2}$ \\ ${ }^{1}$ Department of Botany, Post Graduate campus, Tribhuvan University, Biratnagar, Nepal \\ ${ }^{2}$ University Department of Botany, T.M. Bhagalpur University, Bhagalpur- 812 007, India \\ *E-mail: niroulab@gmail.com
}

\begin{abstract}
Aquatic macrophytes of three freshwater bodies of Biratnagar and adjoining areas in eastern Nepal namely, Betana-a natural oxbow pond, Bhattapokhari-an aged derelict depression, and Singhia river were analysed for their importance value index (IVI), diversity indices and biomass seasonally from January 2008 to December 2009. Singhia river had high species richness-d (2.08-3.84) and Shannon Wienner index-H' (2.16-2.68). Betana pond and Bhattap okhari had low diversity indices; however, nutrient rich Bhattapokhari had highest primary productivity $\left(2675.5 \mathrm{~g} / \mathrm{m}^{2} / \mathrm{yr}\right)$ in comparison to Betana pond $(303.7$ $\left.\mathrm{g} / \mathrm{m}^{2} / \mathrm{yr}\right)$ and Singhia river $\left(479.09 \mathrm{~g} / \mathrm{m}^{2} / \mathrm{yr}\right)$. Seasonally vittates dominated Betana pond had IVI range between 6.3 and 258.8 and biomass range between $168.1 \pm 7.3$ and $265.8 \pm 38.7 \mathrm{~g} / \mathrm{m}^{2}$ ); pleustop hytes dominated Bhattapokhari had IVI range between 41.6 and 192.8 and biomass range between $925.5 \pm 353.2$ and $2020.02 \pm 213.1 \mathrm{~g} / \mathrm{m}^{2}$ ) , and hyperhydate dominated Singhia river had IVI ranged between 2.5 and 160.9 and biomass ranged between $120.7 \pm 55.8$ and $283.5 \pm 28.3 \mathrm{~g} / \mathrm{m}^{2}$.
\end{abstract}

Key words: Growth form, species richness, productivity, oxbow pond, Singhia river.

\section{Introduction}

Aquatic macrophytes form important components whose abundance influences the structural and functional characteristics of aquatic ecosystems (Canfield, 1984). They affect the species composition and richness of aquatic biota and finally the water quality through consequent nutrient cycling. They often act as nutrient pump, take up nutrients from the bottom sediments, translocating them to the shoots and releasing them in the water body when they perish. In the aquatic environment they are essential for manufacturing and producing food for aquatic heterotrophic communities and contribute significantly to the total primary production (Adoni \& Yadav, 1985).

Some floristic and resource based works on aquatic macrophytes are available but quantitative status is almost unknown to Nepal, few of them include Burlakoti \& Karmacharya (2004), Shrestha (1997, 2000) and Upadhy ay (2008). Present work aims to highlight importance value index (IVI), diversity indices and biomass from three fresh water bodies- Betana pond, Bhattapokhari (stagnant) and Sin ghia river (flowing) at Biratnagar and adjoining areas, eastern Nepal. 


\section{Mate rial and Methods}

\section{Study area}

Biratnagar township $\left(26^{\circ} 20^{\prime} \mathrm{N}\right.$ and $\left.87^{\circ} 16^{\prime} \mathrm{E}, 72 \mathrm{~m} \mathrm{msl}\right)$ is characterized by pollution / nutrient loaded derelict depressions and other water bodies- ponds, pools, ditches along the roadsides due to municipal and industrial discharges and agricultural run off.

An aged perennial derelict depression- Bhattapokhari (1.5 ha) $1 \mathrm{~km}$ south from Post Graduate campus surrounded by cultivated land from Biratnagar township (water depth $0.5-1 \mathrm{~m})$, Singhia river- a small perennial flowing water body at the eastern boarder of Biratnagar township and Betana $\left(26^{\circ} 39^{\prime} \mathrm{N}\right.$ and $\left.87^{\circ} 25^{\prime} \mathrm{E}, 115 \mathrm{~m} \mathrm{msl}\right)$, spreaded in 5.5 ha at the Charkoshe Jhadi- a natural oxbow pond (water depth 1-1.5 m) about $26 \mathrm{~km}$ north east away from Biratnagar township were selected for the present study.

The study area has alluvial soil, tropical monsoon climate with three distinct seasons viz., winter (November-February), summer (March-June) and rainy (July-October) in a year. The average annual rainfall is $1312 \mathrm{~mm}$, and average annual maximum and minimum temperatures $30.6^{\circ} \mathrm{C}$ and $14.2^{\circ} \mathrm{C}$, respectively.

Observation and sampling of aquatic macrophytes were made from January 2008 to December 2009. They were sampled by harvest method at monthly intervals using a quadrat of $50 \times 50 \mathrm{sq} \mathrm{cm}$ with adequate numbers. Collected samples were washed and brought to the laboratory and after proper sorting and processing oven dried to constant weight at $80^{\circ} \mathrm{C}$. Importance value index was calculated by summing relative density, relative frequency and relative coverage of the species (Zobel et al., 1987). Coverage was determined by Braun-Blanquet cover-class scale. Diversity indices were calculated following Margalef (1958), Pielou (1966), Shannon Weaver (1963) and Simpson (1949). The annual net production of aquatic macrophytes was calculated by summing positive increments on successive sampling dates during the study period (Singh \& Yadava, 1974). The plant species were identified with the help of standard literature (Hooker, 1887-1897; Cook, 1996) and visual inspection. The identified specimens were confirmed by making crosschecks with the specimens housed at the Tribhuvan University Herbarium (TUH), Department of Botany, Post Graduate Campus, T.U., Biratnagar Nepal and Herbarium Section, University Department of Botany, T.M. Bhagalpur University, Bhagalpur, India. The specimens were deposited at Tribhuvan University Herbarium (TUH) for reference.

\section{Results and Discussion}

Thirty eight aquatic macrophyte species- Betana pond (7), Bhattapokhari (6), and Sin ghia river (32) were recorded with helophytes (7), tenagop hy tes (10), hyperhy dates (11), vittates (7) and pleustophytes (3) by their growth form categories (Table 1). Emergents (helophytes, tenagophytes, hyprehy dates) outnumbered submerged (vittates) and free floating (pleustophytes) as substantiated by Burlakoti and Karmacharya (2004), Sheerwani (1962) and Shrestha (1996, 1998). Betana pond was dominated with vittates and that of Bhattapokhari and Singhia river by hyperhy dates. Species richness $(d)$ and Shannon Weinner index $\left(\mathrm{H}^{\prime}\right)$ were higher in the Singhia river $\left(\mathrm{d}=3.84, \mathrm{H}^{\prime}=2.68\right)$ during winter but the values were lower $\left(\mathrm{d}=2.08, \mathrm{H}^{\prime}=2.16\right)$ during rainy season. Betana pond showed higher species richness and Shannon Weinner index $\left(\mathrm{d}=0.94, \mathrm{H}^{\prime}=1.58\right)$ during rainy (Table 4$)$. Bhat tapokhari had similar 
trend for Shannon Weinner index $\left(\mathrm{H}^{\prime}=0.85\right)$, however, species richness was maximum $(\mathrm{d}=0.69)$ and minimum $(\mathrm{d}=0.55)$ during summer and winter, respectively.

Table 1. Floristic composition of aquatic macrophytes in Betana pond (I), Bhattapokhari (II) and Singhia river (III). (+) presence, (-) absence.

\begin{tabular}{|c|c|c|c|c|}
\hline \multirow{2}{*}{ Growth forms } & \multirow{2}{*}{ Name of plants } & \multicolumn{3}{|c|}{ Site } \\
\hline & & $\mathbf{I}$ & II & III \\
\hline \multirow[t]{7}{*}{ Heloph ytes } & Alternanthera. sessilis (L.) DC. & - & - & + \\
\hline & Commelina benghalensis $\mathrm{L}$. & - & - & + \\
\hline & Cynodon dactylon $\mathrm{L}$. & - & - & + \\
\hline & Cyperus compressus $\mathrm{L}$. & - & - & + \\
\hline & Eclipta prostrata (L.) L. & - & - & + \\
\hline & Gnaphalium polycaulon Pers. & - & - & + \\
\hline & Sphaeranthus indicus $\mathrm{L}$. & - & - & + \\
\hline \multirow[t]{10}{*}{ Tenagoph ytes } & Colocasia esculenta (L.) Schott. & - & - & + \\
\hline & Cyperus difformis $\mathrm{L}$. & - & - & + \\
\hline & Fimbristylis miliacea (L.) Vahl & - & - & + \\
\hline & Hemarthria compressa (L.f.) R.Br. & - & - & + \\
\hline & Hygrophila polysperma (Roxb.) T. Anders & - & - & + \\
\hline & Ludwigia perennis $\mathrm{L}$. & - & - & + \\
\hline & Polygonum barbatum (L.) Hara & - & - & + \\
\hline & P. hydropiper $\mathrm{L}$. & - & - & + \\
\hline & Rumex dentatus $\mathrm{L}$. & - & - & + \\
\hline & Veronica anagallis-aquatica $\mathrm{L}$. & - & - & + \\
\hline \multirow[t]{11}{*}{$\overline{\text { Hype rhy dates }}$} & Alternanthera philoxeroides Griseb & - & + & + \\
\hline & $\begin{array}{l}\text { Ipomoea camea Jacq. subsp. Fistulosa (Mart. } \\
\text { ex Choicy) D.F. Aust in }\end{array}$ & - & + & + \\
\hline & Marsilea crenata Presl & - & - & + \\
\hline & Oenanthera javanica (Blume) DC. & - & - & + \\
\hline & Panicum psilopodium Trin. & + & - & + \\
\hline & Paspalum distichum $\mathrm{L}$. & - & - & + \\
\hline & Polygonum lapathifolium L. & - & - & + \\
\hline & Ranunculus scleratus L. & - & - & + \\
\hline & Sacciolepis interrupta (Willd.) Stapf & - & - & + \\
\hline & Schoenoplectus mucronatus (L.) Palla & - & - & + \\
\hline & Typha angustifolia $\mathrm{L}$. & - & + & - \\
\hline \multirow[t]{7}{*}{$\overline{\text { Vittates }}$} & Blyxa japonica (Miq.) Maxim & + & - & - \\
\hline & Ceratophyllum demersum $\mathrm{L}$. & + & - & - \\
\hline & Chara schweinitzii A. Braun & - & + & - \\
\hline & Enydra fluctuans Lourerio & + & - & - \\
\hline & Hydrilla verticillata (L.f.) Royle & - & - & + \\
\hline & Lymnophila heterophylla (Roxb.) Benth. & + & - & - \\
\hline & Potamogeton crispus L. & - & + & + \\
\hline \multirow[t]{3}{*}{$\overline{\text { Pleustophytes }}$} & Azolla imbricata (Roxb.) Nakai & + & - & + \\
\hline & Eichhornia crassipes (Mart.) Solms. & - & + & + \\
\hline & Pistia stratioites $\mathrm{L}$. & + & - & + \\
\hline
\end{tabular}

Sin ghia river had higher values of equitability $(\mathrm{e}=0.79-0.88)$ and Simpson index $(\mathrm{c}=$ 0.85-0.92) than Betana pond $(\mathrm{e}=0.40-0.92, \mathrm{c}=0.32-0.77)$ and Bhat tapokhari $(\mathrm{e}=$ 0.27-0.61, $\mathrm{c}=0.14-0.48$ ) showing seasonal variation (Table 2). This trend may be attributed to the increase in species richness with decrease in water depth (Burlakoti \& Karmacharya 2004; Van der Valk \& Davis 1976). 
Table 2. Seasonal changes in biomass of different growth form communities of aquatic macrophytes at three sites. $(\mathrm{W}=$ winter, $\mathrm{S}=$ summer, $\mathrm{R}=$ rainy; figure in parenthesis represent $\mathrm{s}$ percentage value).

\begin{tabular}{|c|c|c|c|c|c|c|c|c|c|}
\hline \multirow{3}{*}{$\begin{array}{l}\text { Growth } \\
\text { form }\end{array}$} & \multicolumn{9}{|c|}{ Biomass $\left(\mathrm{g} / \mathrm{m}^{2}\right)$} \\
\hline & \multicolumn{3}{|c|}{ Betana pond } & \multicolumn{3}{|c|}{ Bhattapokhari } & \multicolumn{3}{|c|}{ Singhia river } \\
\hline & W & $\mathbf{S}$ & $\mathbf{R}$ & W & $\mathbf{S}$ & $\mathbf{R}$ & W & $\mathbf{S}$ & $\mathbf{R}$ \\
\hline Helophytes & - & - & - & - & - & - & $8.55(8.8) 2$ & $26.1(6.3)$ & $\begin{array}{c}3.4 \\
(1.7)\end{array}$ \\
\hline Tenagophytes & - & - & - & - & - & - & $\begin{array}{c}103.48 \\
(49.3)\end{array}$ & $\begin{array}{c}155.92 \\
(37.3)\end{array}$ & $8.29(4.2)$ \\
\hline Hyperhydates & $\begin{array}{l}32.1 \\
(9)\end{array}$ & - & $11.4(5.3)$ & $\begin{array}{l}288.6 \\
(29.3)\end{array}$ & $\begin{array}{l}414.7 \\
(35.5)\end{array}$ & $\begin{array}{l}942.2 \\
(45.7)\end{array}$ & $\begin{array}{l}74.11 \\
(35.3)\end{array}$ & $\begin{array}{c}199.05 \\
(47.7)\end{array}$ & $\begin{array}{l}162.15 \\
(81.2)\end{array}$ \\
\hline Vittates & $\begin{array}{c}229.54 \\
(65)\end{array}$ & $\begin{array}{c}155.99 \\
(93)\end{array}$ & $\begin{array}{l}191.4 \\
(89.3)\end{array}$ & $45.7(4.6)$ & $62.1(5.4)$ & - & $4.65(2.2)$ & $\begin{array}{l}15.75 \\
(3.8)\end{array}$ & $\begin{array}{l}16 \\
(8)\end{array}$ \\
\hline Pleustophytes & $\begin{array}{c}21.02 \\
(6) \\
\end{array}$ & $\begin{array}{c}12.1 \\
(7)\end{array}$ & $11.5(5.4)$ & $\begin{array}{r}650.7 \\
(66.1) \\
\end{array}$ & $\begin{array}{l}689.3 \\
(59.1) \\
\end{array}$ & $\begin{array}{r}1120.5 \\
(54.3) \\
\end{array}$ & $\begin{array}{c}9.3 \\
(4.4) \\
\end{array}$ & $20.5(4.9)$ & $\begin{array}{c}9.7 \\
(4.9) \\
\end{array}$ \\
\hline Total & 352.66 & 168.09 & 214.3 & 985 & 1166.1 & 2062.7 & 210.09 & 417.32 & 199.54 \\
\hline
\end{tabular}

IVI as an index of dominance, in each growth form ranged 2.5-258.8, seasonally in these water bodies (Table 3). Vittates had maximum IVI (258.8) during rainy followed by pleustophytes IVI (152.3) during winter and hy perhy dates IVI (6.3) the least during winter at Betana pond. The order of IVI values with respect to seasons at Bhattapokhari: pleustophytes IVI (192.8) rainy > vittates IVI (144.6) winter > hyperhydates IVI (107) rainy; Singhia river: hyperhydates IVI (160.9) rainy > tenagophytes IVI (103.3) winter > pleustophy tes IVI (64.9) summer > helophytes IVI (42.3) winter > vittates IVI (35.7) rainy were recorded. Burlakoti and Karmacharya (2004) reported seasonal average values in the order: emergents IVI (131.42) > submerged IVI (80.79) > free floating IVI (59.14) > rooted floating (28.47) of aquatic macrophytes of Beeshazar Tal, Chitwan, Nepal. Summer season was reported to be most favourable for emergents, winter- for free floating, spring- for submerged and summer- for rooted floating. In the present study, rooted floating leaved (epihy dates) species were absent but occurrence of maximum IVI at Singhia river for emergents was similar to the condition of Beeshazar Tal.

Table 3. Seasonal variation in importance value index (IVI) of different growth form communities of aquatic macrophytes at three sites. $(\mathrm{W}=$ winter, $\mathrm{S}=$ summer, $\mathrm{R}=$ rainy $)$.

\begin{tabular}{|c|c|c|c|c|c|c|c|c|c|}
\hline \multirow{3}{*}{ Growth form } & \multicolumn{9}{|c|}{ IVI } \\
\hline & \multicolumn{3}{|c|}{ Betana pond } & \multicolumn{3}{|c|}{ Bhattapokhari } & \multicolumn{3}{|c|}{ Singhia river } \\
\hline & W & $\mathbf{S}$ & $\mathbf{R}$ & W & $\mathbf{S}$ & $\mathbf{R}$ & W & $\mathbf{S}$ & $\mathbf{R}$ \\
\hline$\overline{\text { Helophytes }}$ & - & - & - & - & - & - & 42.3 & 30.8 & 24.8 \\
\hline Tenagophytes & - & - & - & - & - & - & 103.3 & 33.9 & 32.8 \\
\hline Hyperhydates & 6.3 & - & 13.4 & 41.6 & 65.7 & 107.2 & 116.9 & 143.5 & 160.9 \\
\hline Vittates & 141.4 & 239.5 & 258.8 & 144.6 & 138.8 & - & 2.5 & 26.9 & 35.7 \\
\hline Pleustophytes & 152.3 & 60.5 & 27.8 & 113.8 & 95.5 & 192.8 & 12.5 & 64.9 & 45.8 \\
\hline Total & 300 & 300 & 300 & 300 & 300 & 300 & 300 & 300 & 300 \\
\hline
\end{tabular}

Variation in biomass (monthly/seasonal) of aquatic macrophytes communities at Betana pond, Bhattapokhari and Singhia river is given in Table 5. Maximum and minimum biomass recorded at Betana pond was $265.8 \pm 38.7 \mathrm{~g} / \mathrm{m}^{2}$ (winter), $168.1 \pm 7.3 \mathrm{~g} / \mathrm{m}^{2}$ (summer); Bhattapokhari $2020.02 \pm 213.1 \mathrm{~g} / \mathrm{m}^{2}$ (rainy), 925.5 \pm 353.2 $\mathrm{g} / \mathrm{m}^{2}$ (winter) and that of Singhia river $283.5 \pm 28.3 \mathrm{~g} / \mathrm{m}^{2}$ (summer), $120.7 \pm 55.8 \mathrm{~g} / \mathrm{m}^{2}$ (rainy) on seasonal basis. Percent contribution to total biomass at maximum and minimum, by growth forms recorded at Betana pond- vittates (65-89.3\%), 
hyperhy dates (0-9\%); Bhattapokhari- pleustophytes (54.3-66.1\%), vittates (0-5.4\%) and Singhia river- hyperhydates (35.3-81.2\%), vittates (2.2-8\%), respectively. Maximum and minimum monthly dry biomass of whole communities recorded were December $\left(379.8 \mathrm{~g} / \mathrm{m}^{2}\right)$, August $\left(109.8 \mathrm{~g} / \mathrm{m}^{2}\right)$; August $\left(2725.2 \mathrm{~g} / \mathrm{m}^{2}\right)$, January $(536$ $\left.\mathrm{g} / \mathrm{m}^{2}\right)$ and February $\left(274.76 \mathrm{~g} / \mathrm{m}^{2}\right)$, December $\left(39.9 \mathrm{~g} / \mathrm{m}^{2}\right)$ at Betana pond, Bhattapokhari and Singhia river, respectively.

Table 4. Seasonal variation in diversity indices of aquatic macrophytes at Betana pond (I), Bhatta pokhari (II) and Singhia river(III).

\begin{tabular}{lccccccccc}
\hline \multirow{2}{*}{ Parameter } & \multicolumn{3}{c}{ Winter } & \multicolumn{3}{c}{ Summer } & \multicolumn{3}{c}{ Rainy } \\
\cline { 2 - 10 } & I & II & III & I & II & III & I & II & III \\
\hline Species richness (d) & 0.86 & 0.59 & 3.84 & 0.73 & 0.69 & 3.45 & 0.94 & 0.66 & 2.08 \\
Shannon Wienner & 0.79 & 0.60 & 2.68 & 1.49 & 0.50 & 2.41 & 1.58 & 0.85 & 2.16 \\
index (H) & & & & & & & \\
Equitability (e) & 0.40 & 0.37 & 0.88 & 0.92 & 0.27 & 0.79 & 0.88 & 0.61 & 0.86 \\
Simpson index (c) & 0.32 & 0.27 & 0.92 & 0.75 & 0.14 & 0.85 & 0.77 & 0.48 & 0.86 \\
\hline
\end{tabular}

Table 5. Biomass $\left(\mathrm{g} / \mathrm{m}^{2}\right)$ and productivity $\left(\mathrm{g} / \mathrm{m}^{2} / \mathrm{yr}\right)$ of aquatic macrophytes communities at Betana pond (I), Bhatt apokhari (II) and Singhia river (III) (mean \pm st andard error).

\begin{tabular}{lccc}
\hline Monthly biomass & I & II & III \\
\hline January & 188.5 & 536 & 101.3 \\
February & 200.5 & 329.06 & 274.76 \\
March & 142.8 & 779.3 & 233.8 \\
April & 175.5 & 992.2 & 380 \\
May & 174 & 1169.3 & 261.2 \\
June & 180.2 & 1459.8 & 259.2 \\
July & 183 & 1583.8 & 199.8 \\
August & 109.8 & 2725.2 & $-*$ \\
September & 247.5 & 1847.1 & $-*$ \\
October & 294.4 & 1924 & 41.79 \\
November & 294.5 & 2126.7 & 98.08 \\
December & 379.8 & 710 & 39.9 \\
\hline Seasonal biomass & \multicolumn{3}{|}{} \\
\hline Winter & $265.8 \pm 38.7$ & $925.5 \pm 353.2$ & $128.4 \pm 43.9$ \\
Summer & $168.1 \pm 7.3$ & $1100.1 \pm 124.6$ & $283.5 \pm 28.3$ \\
Rainy & $208.6 \pm 67$ & $2020.02 \pm 213.1$ & $120.7 \pm 55.8$ \\
\hline Producti vity & 323.7 & 2675.7 & 479.09 \\
\hline
\end{tabular}

Seasonal biomass represents average of monthly values. * No biomass was recorded due to over flooding in river.

Ambasht (1971) reported $2.21 \mathrm{~kg} / \mathrm{m}^{2}$ dry biomass in shallow zone with emergent vegetation and $0.57 \mathrm{~kg} / \mathrm{m}^{2}$ in floating leaved Trapa bispinosa central zone from a non polluted small pond in the Banaras Hindu University campus (India). Mean standing crop of floating macrophyte (Eichhornia crassipes) was 561.0-619.96 g dry wt $/ \mathrm{m}^{2}$ and that of submerged macrophyte (Hydrilla verticillata, Potamogeton crispus) was 166.27-167.18 g dry $\mathrm{wt} / \mathrm{m}^{2}$ in a eutrophic pond of Bhagalpur (Sharma \& Rai, 1989). In marshy and attached emergents dominated macrophytes at Kewar lake wetland, Bihar, India, monthly biomass ranged $114-230 \mathrm{~g} / \mathrm{m}^{2}$, maximum- December and minimumJuly (Sharma, 1995). Pandey et al. (1995) reported $597.4 \mathrm{~g}$ dry $\mathrm{wt} / \mathrm{m}^{2} / \mathrm{yr}$ macrophytic productivity of Kewar lake wetland (Begusarai), Bihar with maximum total dry wt biomass $2077.12 \mathrm{~g}$ dry $\mathrm{wt} / \mathrm{m}^{2}$ at November and minimum $843.09 \mathrm{~g} \mathrm{dry} \mathrm{wt} / \mathrm{m}^{2}$ at June. 
Biomass of macrophytic community in the selected wetlands of B iratnagar, Nepal ranged 118.4-2039.6 g/m² (Upadhyay, 2008). Minimum was reported in September from submerged paddy field and maximum from Typha community dominated marshland- Koshi Tappu Wildlife reserve in June. Biomass reported from other communities was: Betana pond $524.8 \mathrm{~g} / \mathrm{m}^{2}$ (March); Singhia river $197.6 \mathrm{~g} / \mathrm{m}^{2}$ (January); ditches $1238 \mathrm{~g} / \mathrm{m}^{2}$ (September); Derelict depression $476 \mathrm{~g} / \mathrm{m}^{2}$ (June) at Biratnagar and adjoining areas, eastern Nepal.

Water hy acinth dominated Bhattapokhari was the most productive $2675.7 \mathrm{~g} / \mathrm{m}^{2} / \mathrm{yr}$ in comparison to natural oxbow pond- Betana $\left(323.7 \mathrm{~g} / \mathrm{m}^{2} / \mathrm{yr}\right)$ and Singhia river (479.09 $\mathrm{g} / \mathrm{m}^{2} / \mathrm{yr}$ ). Water hyacinth is one of the most productive plant of the world (Sinha \& Sahai, 1979). This plant has exhibited its phenological rhy thms related to temperature gradients, since gradual increase in biomass during summer and significant decrease during winter months. In Ramgarh wetland of Gorakhpur (India), Sinha (1969) calculated $930 \mathrm{~g} / \mathrm{m}^{2} / \mathrm{yr}$ production in emergent zone and a little over $1000 \mathrm{~g} / \mathrm{m}^{2} / \mathrm{yr}$ in floating and submerged zones. In temperate climate of Srinagar (Kashmir, India), Kaul (1971) found $2800 \mathrm{~g} / \mathrm{m}^{2} / \mathrm{yr}$ productivity in the emergent and $880 \mathrm{~g} / \mathrm{m}^{2} / \mathrm{yr}$ in floating zone of Dal lake.

\section{Acknowle dge ments}

We thank Prof. S.N. Jha, Head, Department of Botany, Post Graduate Campus, T.U., Biratnagar Nepal for providing laboratory facilities, constant encouragements, and his help in plant identification. The first author is thankful to Head, University Department of Botany, T.M. Bhagalpur University, India for guidance and laboratory facilities. The author is also grateful to Prof. A.K. Pandey, University Department of Delhi, India for guid elines; Institute of Science and Technology, Tribhuvan University (T.U.) Nepal for Ph.D. leave and UGC, Nepal for partial financial assistance.

\section{References}

Adoni, A.D. \& M. Yadav. 1985. Chemical and productional characteristics of Potamogeton pectinatus L. and Hydrilla verticillata Roy le in an eutrophic lake. In: Bulletin of Botanical Socciety (Ed. A.D. Adoni). Sagar. pp. 96-105.

Ambasht, R.S. 1971. Ecosystem study of a tropical pond in relation to primary production of different vegetation zones. Hydrobiologia 12: 57-61.

Burlakoti, C. \& S.B. Karmacharya. 2004. Quantitative analysis of macrophytes of Beeshazar Tal, Chitwan, Nepal. Himalayan Journal of Sciences 2(3): 37-41.

Canfield, D.E., J.V. Shirman \& J.R. Jones. 1984. Assesing the trophic status of lakes with aquatic macrophytes. Lakes \& Reservoir Management 1: 446-450.

Cook, C.D.K. 1996. Aquatic and wetland plants of India. Oxford University Press, Oxford-New York-Delhi.

Hara, H. \& L.H. Williams. 1979. An enumeration of the flowering plans of Nepal Vol. 2. British Museum (Nat. Hist). London.

Hara, H., A.O. Chater \& L.H. Williams. 1982. An enumeration of the flowering plants of Nepal Vol. 3. British Museum (Nat. Hist). London.

Hara, H.W., T. Stearn \& L.H. Williams. 1978. An enumeration of the flowering plants of Nepal Vol. 1. British Museum (Nat. Hist). London.

Hooker, J.D. 1872-1897. The flora of British India, 7 volumes L. Reeve, London.

Kaul, V. 1971. Production and ecology of some macrophytes of Kashmir lakes. Hydrobiologia 12: 63-69.

Margalef, R. 1958. Information theory on ecology . General systematics 3: 36-71. 
Pandey, K.N., V. Prakash \& U.P. Sharma. 1995. Assessment of primary productivity of phytoplankton and macrophytes of Kewar lake wetland (Begusarai), Bihar. Journal of Freshwater Biology 7(4): 237-239.

Pielou, E.C. 1966. The measurement of diversity in different types of biological collections. Journal of Theoretical Biology 13: 131-144.

Shannon, C.E. \& W. Weaver. 1963. The mathmetical theory of communication. University of Illnois press, Urbana, USA.

Sharma, U.P. 1995. Role of macrophytes in the ecosystem of Kewar lake wetland (Begusarai), Bihar, India. J. Freshwater Biol. 7(2): 123-128.

Sharma, U.P. \& D.N. Rai. 1989. Biomass of hydrophytes in an eutrophic pond of Bhagalpur (Bihar). Journal of Freshwater Biology 1(2): 173-176.

Sheerwani, A.B. 1962. A study on the hydrophytes and plants of low ly ing habitats in Jabalpur. Bulletin of Botanical Survey, India. 4(1-4): 227-231.

Shrestha, P. 1996. Diversity of aquatic macrophytes in the Koshi Tappu Wildlife Reserve and Surrounding areas, eastem Nepal. In: Environment and Biodiversity in the context of South Asia (Eds. P.K. Jha, G.P.S. Ghimire, S.B. Karmachary a \& P. Lacoul). Ecological Society (ECOS), Kathmandu. pp. 203-211.

Shrestha, P. 1997. Ecological study on aquatic macrophyte vegetation of lake Phewa and lake Rupa, Nepal. Ph.D. Thesis, University of Vienna, Australia. $366 \mathrm{p}$.

Shrestha, P. 1998. Aquatic macrophyte vegetation of lake Ghodaghodi, Western Nepal: existing status and management perspectives. A report submitted to the IUCN/ Nepal.

Shrestha, P. 2000. Vegetation analysis of aquatic macrophytes by using line intercept in lake Phewa, Nepal. Ecoprint 7(1): 7-14.

Simp son, E.H. 1949. Measurement of diversity. Nature 163: 688.

Singh, J.S. \& S.P. Yadava. 1974. Seasonal variation in composition, plant biomass and net primary productivity of a tropical grassland of Kurukshetra, India. Ecological Monographs 44: 351-376.

Sinha, A.B. 1969. Investigation on the ecology of Ramgarh lake. Ph.D. Thesis, Gorakhpur University, Gorakhpur.

Sinha, A.B. \& R. Sahai. 1978. Studies on the factors affecting growth and productivity of free floating macrophytes in Ramgarh lake, Gorakhpur. In: Glimpses of ecology (Eds. J.S. Singh \& B. Gopal). International Scientific Publisher, Jaipur. pp. 377382.

Upadhy ay, B.P. 2008. Use of aquatic macrophytes as a low cost water quality monitoring tool at Biratnagar, Nepal. Report submitted to the Dean, Institute of Science and Technology (IOST), Tribhuvan University, Kirtip ur, Kathmandu.

Vander valk A.G. \& C.B. Davis. 1976. Changes in the composition, structure and production of plant communities along a perturbed wetland coenocline. Vegetation 32: $87-96$.

Zobel, D.B., P.K. Jha, U.K. Yadav \& M.J. Behan. 1987. A practical manual for ecology. Kathmandu, Ratna Book Distributors. 149 p. 